\title{
Genetic and biochemical studies on some Egyptian wheat genotypes under drought stress
}

\author{
Samy A. A. Heiba, Samira A. Osman, Sara E. I. Eldessouky, Atef A. A. Haiba and Rania T. Ali ${ }^{*}$ (i)
}

\begin{abstract}
Background: Strategic crops need to be screened from time to time to select the most tolerant and stable genotypes incompatible with environmental conditions. This research experiments were carried out to screen thirteen Egyptian wheat genotypes under water regime stress to select the most tolerant genotypes to drought conditions in two successive seasons. The studied genotypes were cultivated in rows, and the irrigation duration period between any two successive irrigations was elongated to double period to supply these genotypes with only $50 \%$ of the water needed in well watering conditions. This evaluation concerned on some yield production indexes such as spike weight, spike length, spike number, grains number/spike the 100 grains weight and stress susceptibility index and the cytogenetic evaluation index of the pollen grains viability on two successive seasons (2017-2018 and 2018-2019). This screening also carried out some biochemical and molecular analysis on the wheat genotypes at the seedling stage by the end of 2018 (the first season of water regime) targeting total protein profile, proline amino acid accumulation and Betaine aldehyde dehydrogenase-1 enzyme gene expression via semiquantitative RT-PCR.
\end{abstract}

Results: Sids 12 genotype recorded the highest SW, SL and SN. Considering the number of grains/plant and the number of spikes/plant are the principal yield components, and 100 grains weight is the principal yield quality, Sids 12 also declared its tolerance to water regime on regarding the plant productivity to grains' number/plant and scored the lowest SSI. Pollen viability and protein profile were also affected as a response to the water regime. Proline concentration in fresh leaves emphasizes the tolerance of Sids 12, Misr 2 and Gemmieza 9 genotypes to the water deficit.

Conclusion: Among the examined genotypes, Sids 12, Misr 2, Shandaweel 1 and Gemmieza 9 and line 20 are recommended to be cultivated in water shortage conditions as they show high performance under water regime conditions.

Keywords: Wheat genotypes, Water regime, Pollen grain viability, SDS-PAGE, Proline, BADH-1 gene expression

\section{Background}

Egypt is a great nation that has built its civilization on the River Nile thousand years ago, depends entirely on the river as a main source of water for life and agriculture. In the last few years, the Egyptian share of Nile water is threatened to be lowered because of the new dam built on the River Nile. And above all this the few past years witnessed climate changes and shortening in the rainy

\footnotetext{
*Correspondence: raniatawfick@hotmail.com

Genetics and Cytology Department, Genetic Engineering

and Biotechnology Division, National Research Centre, P.O.Box 12622, Giza, Egypt
}

days which in turn extended their shadows to the plant breeding strategies and represent a new challenge to the researchers and plant breeders to pay attention on screening the existing germplasm of various crops under drought stress to identify tolerant genotypes and their subsequent incorporation into breeding programs and to produce some new lines with high productivity and adaptation to the new Egyptian weather conditions.

Wheat (Triticum aestivum L.) family Poaceae (Gramineae) is one of the world's most crucial cereal crops. It comprises human and animal foods. Egyptian people consume about sixteen million tons of wheat per year; 8.795 million/ton are planted in Egypt, the rest of 
them are imported from abroad (Agricultural ministry flying pursuer, agricultural pesticide committee 2019). The Government is giving a great importance to increase the productivity of wheat, whether through vertical expansion by supplying the wheat farmers with all their needs and requirements such as fertilizers, pesticides, advices, and with support the laboratory works to provide new researches in improving plants productivity and quality, or through horizontal expansion by cultivating it in new and reclaimed lands to fill the food gap between what we need and what we produce. Optimistically, 2019 witnesses that, the exhibited efforts put Egypt in the fifth place in the high grain productivity of wheat per planted area.

According to the Egyptian wheat atlas; some of the drought-tolerant wheat genotypes such as Sids 12 and Shandaweel1 are being recommended to be planted in upper Egypt where there are few rains fall and high temperature, while some other genotypes such as Giza 168, Giza 171, Misr 1\& 2 and Sakha 93 are recommended to be planted in north Egypt as they are sensitive to water shortage.

It is well known that drought is highly complex stress affect the plant growth and development, reduces some vital activities in plants, such as nutrient uptake by the roots and transport to the shoots, because of restricted transpiration rates and impaired in addition to membrane permeability (Alam 1999).

Water deficiency manifested primarily as osmotic stress, resulting in the disruption of homeostasis and ion distribution in the cell (Zhu 2001).

The wheat tolerance to drought stress depends on factors such as the genotype, the stress intensity, the duration of the stress and the phenological stages (vegetative or reproductive), whereas the plants are more sensitive (Yadav et al. 2020).

The prerequisite to produce a more resistant genotype depends on screening the plant performance and productivity. Based upon this, ten wheat genotypes and the other three lines were screened for their tolerance to the water regime. The screening validation considering some agro-morphological traits that can describe the wheat yield, such as spike weight (SW), spike length (SL), number of spike (SN) and number of grains (GN)/plant which has been suggested as a selection criterion for drought tolerance (Shpiler and Blum 1991), in addition to the 100 grains weight which may refer to the yield quality. This work also regarded the seedling stage under water regime stress and took some molecular analysis on: total protein profiling, proline amino acid accumulation and betaine aldehyde dehydrogenase 1 (BADH-1) gene expression by using semiquantitative RT- PCR as a mark of gene activity.
It is well known that the reproductive stage is a very sensitive stage in which the parent plant can transfer the genetic material into the embryo (Mendieta and Granados 2015), if the parent plants were exposed to the abiotic stress such as water deficits at flowering and pollination stage thus will indeed affect the reproductive tissues. Male reproductive was more sensitive to abiotic stress such as heat stress (Hedhly 2011). A number viable pollen grains can be reliable; as the well-adapted parent plant will produce a higher yield under stress, it indicates that its genotype is in tolerance to that stress (Sakhi et al. 2014). Based upon that, the screening validation of the examined wheat concerned the pollen grains number and viability, because of knowing that abiotic stress may enhance the plant cells to produce ROS (Reactive Oxygen Species) which is very toxic and has a damaging effect on the proteins, lipids, carbohydrates and DNA (Zlatev and Lidon 2012).

Proline amino acid compound is one of the compatible osmolytes, known to contribute to the osmotic adjustment, work on ROS detoxification, protect the cell membrane integrity and tolerance of plants; it plays an important role to increase the ability of cells to retain water without affecting the normal metabolism (Hayat et al. 2012).

Proline amino acid accumulation levels reflect the plants' response under water regime to that stress; proline accumulation points to that the stressed plants have developed dynamic responses at the biochemical level allowing them to escape and/or adapt to unfavorable environmental conditions (Zandalinas et al. 2017).

Studying the stress effect on the level of gene expression is also reliable to configure the mode of action of such stress on the genetic materials DNA and RNA. Betaine aldehyde dehydrogenase (BADH) is a vital enzyme that catalyzes the conversion of betaine aldehyde (BA) to glycine betaine (GB) which has an osmo-protectant the cell under stresses enhancing the tolerance to a wide range of stresses in many crops (Yu et al. 2017).

Based on the above, thirteen Egyptian wheat genotypes were evaluated using some yield criteria, biochemical and molecular analysis at seedling stage targeting total proteins profile, proline amino acid accumulation and Betaine aldehyde dehydrogenase- 1 enzyme gene expression via semiquantitative RT- PCR.

\section{Methods}

Thirteen genotypes of Egyptian "Wheat" (Triticum aestivum L.) include ten cultivars, and three lines were obtained from Agriculture Research Centre.

The genotypes were grown in Nubaria farm, National Research Centre in two successive seasons 2017-2018 and 2018-2019. The experiment was conducted at the 
beginning of September 2017, in a randomized complete design with three replications. The studied genotypes were cultivated in rows in sand soil fertilized with NPK in two groups. Group (A) represents the well-watered plant as a (-ve) control, and group (B) represents the plant under water regime as (+ve) control. In group (B), the irrigation duration period between any two successive irrigations was elongated to double period to supply these genotypes with nearly $50 \%$ water needed in wellwatering conditions to resemble the water deficit.

\section{Yield criteria studies}

The thirteen wheat genotypes (Table 1) were compared at water regime for some yield traits (spike weight (SW), spike length (SL), number of spikes (SN), grains number (GN)/spike the 100 grains weight and stress susceptibility index (SSI). The yield traits observations were recorded at the harvesting stage.

Duncan's statistical package was used to differentiate the degree of drought resistance between studied genotypes depending on the studied yield criteria by using
SPSS program version. The stress susceptibility index (SSI) was calculated for the grain yield for each genotype using the following formula (Fischer and Maurer 1978):

$$
\mathbf{S S I}=\left[\mathbf{1}-\left(\mathbf{G Y}_{\mathbf{S}} / \mathbf{G Y}_{\mathbf{P}}\right)\right] / \mathbf{1}-\mathbf{D}
$$

where $\mathrm{GY}_{\mathrm{S}}$ is the mean of genotype under stress, $\mathrm{GY}_{\mathrm{P}}$ is the mean of un-stressed genotype and D is the ratio of the overall means of all genotypes under stress to the overall means of un-stressed genotypes.

\section{Cytogenetic studies}

After the complete emerge of the flowering spikes, spikes were brought from the field into the laboratory in wet tissue paper. Then pollen grains were removed from the yellowish anthers at the center of each spikelet (Zadoks et al. 1974). A minimum of three anthers from at least 3-4 flower buds of suitable size of each plant was excised with a sharp needle and placed on a slide (Fig. 1a). A pollen sample was taken in a drop of $1 \%$ 2, 3, 5 triphenyl tetrazolium chloride (TTC) in the 5\%

Table 1 Names and pedigree of examined wheat genotypes

\begin{tabular}{|c|c|c|}
\hline $\mathbf{N}$ & Genotype & Pedigree \\
\hline 1 & Sakha 94 & Opata/Rayon//Kauz \\
\hline 2 & Sakha 93 & Sakha 92/TR 810328 S $8871-1 S-2 S-1 S-0 S$ \\
\hline 3 & Gemmieza 10 & Maya 74"S"/On//1160-147/3/Bb/4/Chat"S"/5/ctow \\
\hline 4 & Misr 2 & SKAUZ/BAV92. CMSS96M03611S-1M-010SY-010M-010SY-8M-0Y-0EGY \\
\hline 5 & Sids 1 & HD2172/Pavon "S"//1158.57/Maya 74"S"Sd46-4Sd-2Sd-1Sd-0Sd \\
\hline 6 & Sids 12 & $\begin{array}{l}\text { BUC//7C/ALD/5/MAYA74/ON//1160.147/3/BB/GLL/4/CHAT"S"/6/MAYA/VUL//CMH74A.63 } \\
\text { 0/4*SXSD70964SD-1SD-1SD-0SD }\end{array}$ \\
\hline 7 & Giza 168 & MIL/BUC//Seri CM93046-8M-0Y-0M-2Y-0B \\
\hline 8 & Misr 1 & OASIS/SKAUZ//4*BCN/3/2*PASTOR. CMSS00Y01881T -050M-030Y-030M-030WGY-33M-0Y-0EGY \\
\hline 9 & Shandaweel1 & SITE//MO/4/NAC/TH.AC//3*PVN/3/MIRLO/BUC. CMSS93B00567S-72Y-010M-010Y-010M-0HTY-0SH \\
\hline 10 & Line 12 & \\
\hline 11 & Line 18 & \\
\hline 12 & Line 20 & \\
\hline 13 & Gemmieza 9 & Ald"S"/Huac"S"//CMH74A.630/5 × CGM4583-5GM-1GM-0GM \\
\hline
\end{tabular}

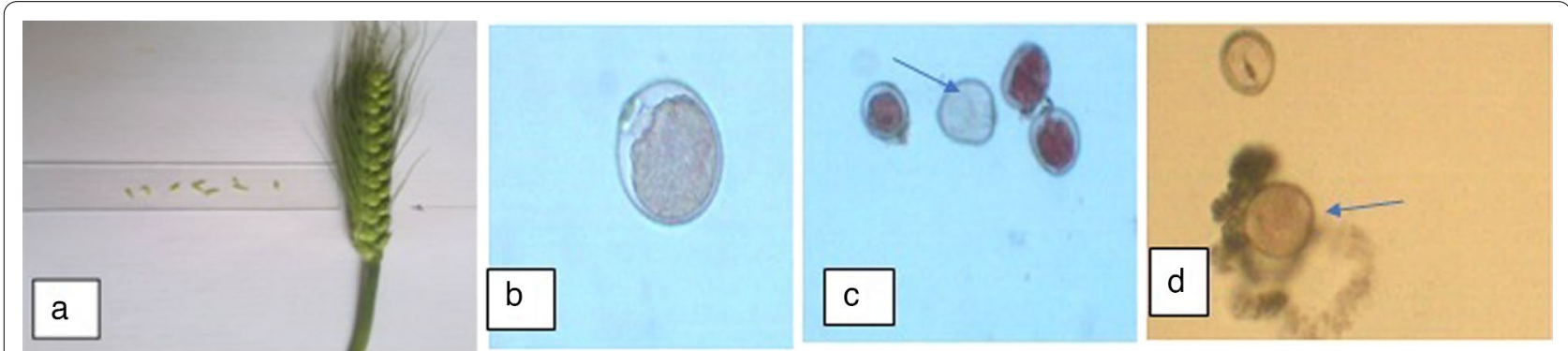

Fig. 1 Anthers at suitable age to study the pollen viability (a), viable pollen grain (b), nonviable pollen grain black arrow (c) and viable pollen grain with germination arrow $(\mathbf{d})$ 
sucrose solution and covered immediately to exclude oxygen, which may inhibit dye reduction. Pollen usually takes the stain in 10-15 min (Khatun and Flowers 1995). Slides were then observed under a light microscope at $20 \times$ magnification at room temperature for viable and nonviable pollen grains. The colored pollen grains of light red to red to deep pink grains are considered viable, while non-colored ones and black ones are considered nonviable (Norton 1966). Viability was calculated on a percentage basis by counting colored pollen grains out of 1000 randomly selected pollen grains in each replicate, and the experiment was carried out in 2-3 replicates.

Pollen viability was calculated by the following equation:

\section{Proline estimation}

Proline was extracted and estimated in $\mu \mathrm{molg}^{-1}$ fresh weight of leaves (Bates et al. 1973). The absorbance was read at $520 \mathrm{~nm}$.

\section{Betaine aldehyde dehydrogenase-1 gene isolation from genomic RNA}

The RNA of six selected genotypes (Sakha 94, Misr 2, Line 18, Sakha 93, Giza 168 and Gemmieza 9) was extracted by SV Total RNA Isolation System Spin Protocol (Promega, USA.). Revert Aid First Strand cDNA Synthesis Kit (thermo, Germany) was used to synthesize cDNA from total RNA. First-strand cDNA synthesis for different isolated RNA was performed in $0.2-\mathrm{ml}$ PCR Eppendorf containing $(20 \mu \mathrm{l})$ consisted of template

Pollen viability $\%=($ number of viable grains/totals counted pollen grains $) \times 100$

\section{Protein electrophoresis}

Sodium dodecyl sulfate-polyacrylamide gel electrophoresis (SDS-PAGE) was performed according to Laemmli (1970), as modified by Studier (1973). Soluble proteins were extracted from leaves of thirteen genotypes. Protein fractionations were performed exclusively on vertical slab gel $(19.8 \mathrm{~cm} \times 26.8 \mathrm{~cm} \times 0.2 \mathrm{~cm})$ using the electrophoresis apparatus manufactured by Cleaver, UK.

\section{Extraction of leave soluble proteins}

One gm of the leaves was grinded and mixed with $1 \mathrm{ml}$ of extraction buffer in Eppendorf tube and left in the refrigerator overnight, then vortexed for $15 \mathrm{~s}$ and centrifuged at $12,000 \mathrm{rpm}$ at $4{ }^{\circ} \mathrm{C}$ for $20 \mathrm{~min}$. The supernatants containing soluble proteins were transferred to new Eppendorf tubes and kept at deep-freeze until use for electrophoretic analysis. The samples were ruined in acrylamide gel $15 \%$ concentration.

The images were captured by a digital camera (Sony, made in Japan) and transferred directly to the computer. Then the protein bands were analyzed by the total Laboratory program to find out the molecular mass of each band and then compare the presence and absence of the band among studied genotypes.
RNA $(5 \mu \mathrm{l})$, Primer oligo $(\mathrm{dt}) 18$ primer $(1 \mu \mathrm{l}), 5 \mathrm{X}$ reaction buffer $(4 \mu \mathrm{l})$, RiboLock RNase inhibitor $(1 \mu \mathrm{l}), 10 \mathrm{mM}$ dNTP Mix $(2 \mu \mathrm{l})$ and RevertAid M-MuLV reverse transcriptase $(1 \mu \mathrm{l})$ then completed to $20 \mu \mathrm{l}$ by nuclease-free water. For oligo (dT) 18 or gene-specific primed cDNA synthesis, incubate for $60 \mathrm{~min}$ at $42{ }^{\circ} \mathrm{C}$ and then terminate the reaction by heating at $70{ }^{\circ} \mathrm{C}$ for 5 min by thermocycler (Bio-Rad).

cDNA from Sakha 94, Misr 2, Line 18, Sakha 93, Giza 168 and Gemmieza 9 in seedling stage (2- or 3-weekold plant) were subjected to a polymerase chain reaction (PCR) for 30 cycles with BADH1 Primer (Shrestha 2011). This primer designed from BADH1 sequences was obtained from the NCBI databases with the following accession numbers Hordeum vulgare BADH1 (AB161712), as shown in Table 2.

PCR amplification for isolation $B A D H$ gene from cDNA was performed in 0.2-ml PCR Eppendorf containing $(50 \mu \mathrm{l})$, which consisted of Dream Taq DNA Polymerase, Promega $(1 \mu \mathrm{l}), 10 \times$ Dream Taq Green Buffer $(10 \mu \mathrm{l})$, $\operatorname{MgCl}(5 \mu \mathrm{l}) \mathrm{dNTP}$ were mixed $10 \mathrm{mM}$ each $(4 \mu \mathrm{l})$, primer forward (f) and reverse $(\mathrm{r})$, Metabion, German $(3 \mu \mathrm{l})$ and template DNA $(4 \mu \mathrm{l})$ or cDNA $(2 \mu \mathrm{l})$. Then, all these components were completed to $50 \mu \mathrm{l}$ by water, nuclease-free. Thermocycler (Bio-Rad) was programmed as follows:

Table 2 The specific primer sequences of $B A D H-1$ and Actin genes

\begin{tabular}{llll}
\hline Primer & Forward primer $\left(\mathbf{5}^{\prime}-\mathbf{3}^{\prime}\right)$ & Reverse primer $\left(\mathbf{5}^{\prime}-\mathbf{3}^{\prime}\right)$ & $\begin{array}{l}\text { Expected } \\
\text { size of } \\
\text { amplicon }\end{array}$ \\
\hline BADH-1 & CAGCAAGAAGTGAAGGTGCTAC & GTACCTGGTGACTTGTTTCACG & $\sim 410$ bp \\
Actin primer & CTGGGATGACATGGGGAAATATGGCA & GCCTTGGAGATCCACATCTGCTGGA & $\sim 850$ bp \\
\hline
\end{tabular}


$94{ }^{\circ} \mathrm{C}$ for 2 min (one cycle) then $94{ }^{\circ} \mathrm{C}$ for $15 \mathrm{~s}, 57^{\circ} \mathrm{C}$ for $30 \mathrm{~s}$ and $72^{\circ} \mathrm{C}$ for $1.5 \mathrm{~min}$ ( 35 cycles).

RT-PCR reactions were loaded on ethidium bromidestained $2 \%$ agarose gel, and quantification of bands revealed during the different runs was performed. Processed data represent pixel intensity (peak height) of the ethidium bromide-stained agarose gel occupied by each band of both target $B A D H-1$ genes and the housekeeping (actin) gene.

\section{Results}

\section{Effect of water regime on yield criteria}

The effect of water regime on yield traits' means such as spike weight, spike length, spikes number, grains number/spike and the weight of 100 grains was determined on studied genotypes in two successive seasons (Tables 3 , 4).

On the level of spike weight: The collected data in the first season declared that sides 12, Gemmieza 9, Sids 1, Shandaweel1, Masr1, and line 12 scored the higher means of spike weight. Prolongation of the drought stress to the second year announces the superiority and high performance of the Sids 12 over all the other genotypes.

Worth to mention that, cultivar Gemmieza 9 under the drought stress for the first year scored the highest spike weight relative to well-watered (control); this was a little bit lowered to be as same as the control on the second season.

The same validation performance revealed that line 18 was the least among all the genotypes in both seasons.

On the level of spike length: In the first year; most of the studied genotypes showed a decrease in the spike length relative to their controls except for Shandaweel1 and line 20.

Prolongation of the drought stress to the second year revealed some improvement in the spike length mean of some genotypes over their control such as Sids 1 and Shandaweel1. The highest spike length value under stress was recorded with Line 12. Also, Gemmieza 9 under stress showed nearly the same mean spike length as its control compared with other genotypes.

On the spikes number/plant level: In the first year, Shandaweel1 recorded the highest performance under drought stress and even exceeded the spikes number in control. Also line 12 showed well adaptation to the stress as it nearly the same spike number scored as its control. In the second year, all the studied genotypes showed a notable decrease in the produced spikes number. By the time, cultivar Gemmieza 9 showed nearly the same value as control. Shandaweell cultivar showed a high value of spikes number and even exceeded its control. The highest spikes number was recorded with Line 12, while the lowest number of spikes was recorded in genotypes (Sakha 94, line 18 and line 20).

On the level of Grains number/spike: The grains number/spike was significantly varied between wheat genotypes as shown in Tables 3 and 4. In the first year, Sids 12, Shandaweel1, Gemmieza 9 and Masr2 showed the highest performance to drought stress. They produced the highest productivity among all the examined genotypes and even exceeded the well-watered control. After prolongation the drought stress to the second year, Sids 12 and Shandaweel1 are still on the front as the most tolerant genotype relative to their control and relative to the other plants, this declares the tolerance of the Sids 12 and Shandaweel 1 to the water regime also its ability to pass the reproductive stage to form grains successfully. Line 18 showed the lowest performance under drought stress.

On the level of 100 grains weight: grain weight index is a quality parameter to assess the grain quality in wheat. In the first season, Gemmieza 9 followed by Sids 12 gave the highest performance under stress even exceeded their controls. Prolongation of the drought stress to the second year, Misr 1 showed the highest grains weight. Also; Gemmieza 9 showed some deterioration in the grains weight in response to the drought stress relative to its control.

The stress susceptibility (SSI) index is an effective measurement to estimate the stress tolerance (when $\mathrm{SSI}<1$ means stress-tolerant and when SSI $>1$ that means genotype relatively stress susceptible). Figure 2 shows that the wheat yields collected data revealed variations between different wheat genotypes. Giza 168 followed by Sids 1 scored the highest SSI emphasizing their susceptibility to the water regime in the first year, while Sids 12 declare its tolerance to the water regime and scored the lowest SSI value. Considering the stress susceptibility index on the level of two seasons, we can easily note that the stress-tolerant genotypes such as Sakha 94, Misr 2, Sids 12, Shandaweel1 and Gemmieza 9 showed some breakdown in their tolerance to the stress in the second year.

\section{Effect of water regime on pollen grain viability}

The obtained data revealed that different wheat genotypes responded to the water regime via viability of pollen grains in a fluctuated way. In the first year, most wheat genotypes produced lowered percentage of viable pollen grains relative to their controls due to the water regime except the Sakha 94, Shandaweel1, line 20 and Gemmieza 9.

Pollen sterility ranged from 1.4 to $7.7 \%$ under normal watered conditions and 2.9 to $8.4 \%$ under drought stress conditions. The highest percentage of pollen viability in the non-stressed plants was 98.6, recorded after Sids 


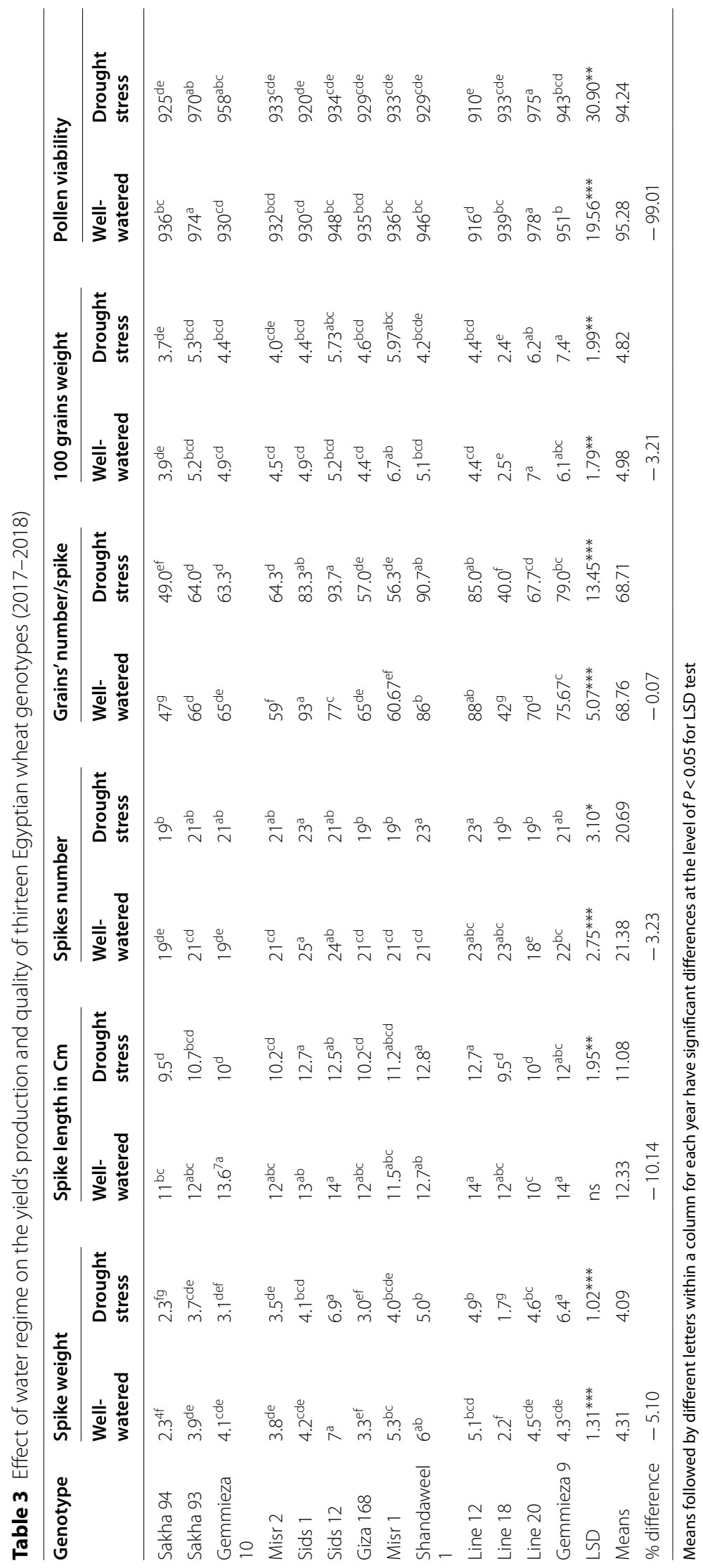




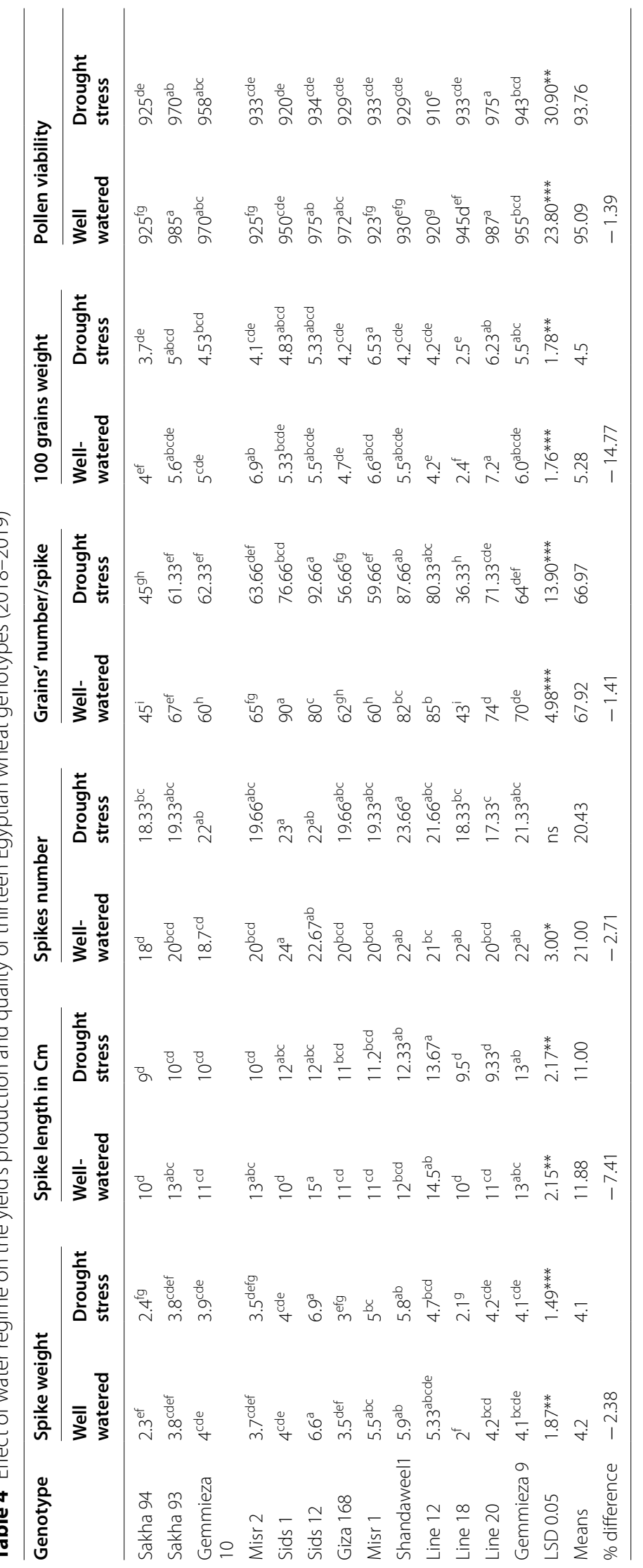




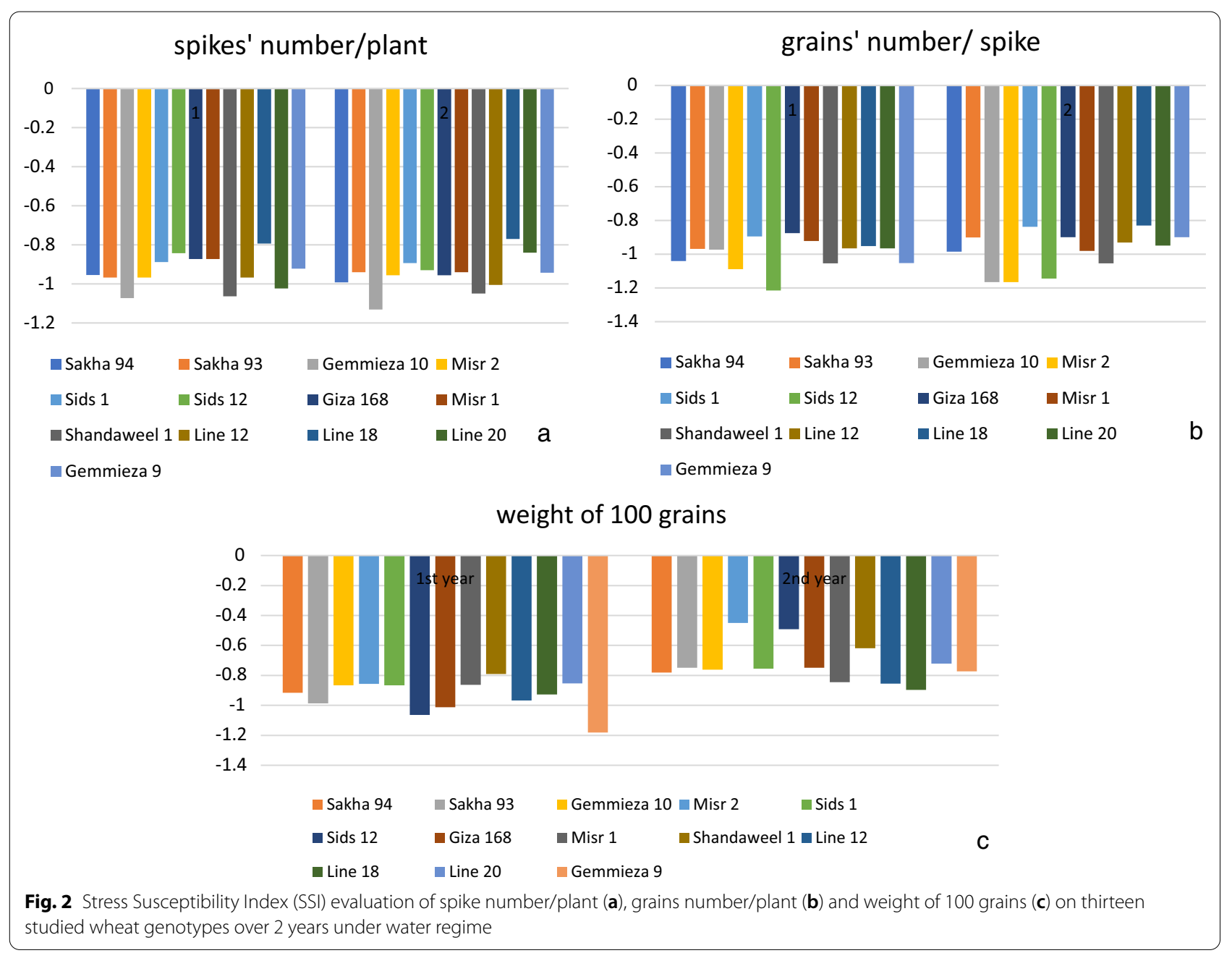

12 and Giza 168. These percentage were lowered as a response to drought stress to reach $94.6 \%$ and $93.6 \%$.

Worth to mention that, by the time Masr1\&2 scored the lowest percentage of pollen viability in well-watered conditions (92.3\%), they showed an improvement in the pollen viability percentage to reach 93.6 and 93.2 after drought stress.

In the second year, Gemmieza 10 and Misr 2\&1 produced a higher percentage of viable pollen grain relative to their controls and their performance in the first year.

Pollen sterility ranged from 1.3 to $8 \%$ under normal watered conditions and 2.5 to $9 \%$ under drought stress conditions. Line 12 recorded the lowest percentage of pollen viability, $92 \%$ after control and $91 \%$ as a response to drought stress.

Line 20 recorded the highest percentage of pollen viability under drought stress (97.5\%).

Misr 1\&2 genotypes emphasized their tolerance to drought stress by produce higher pollen viability relative to the non-stressed plants.

\section{Effect of water regime on total proteins pattern using SDS-PAGE}

The water regime stress had a significant effect on the expiration of some genes; their influence could be studied through proteins banding patterns using the SDSPAGE technique. In the first season, the total proteins pattern of thirteen wheat genotypes was examined under drought stress, as shown in Fig. 3a, b.

The total number of bands was 35 with molecular weight ranged from 135 to $5 \mathrm{KDa}$, from which 15 bands were monomorphic, while 20 bands were polymorphic, as shown in Table 5.

Among the examined genotypes, only Gemmieza 10 and line 20 showed unchanged protein bands number after being stressed by the water regime relative to the well-watered plants. Worth to mention that line 18 responded to the water regime by showing higher bands number by two new bands relative to wellwatered plants. 


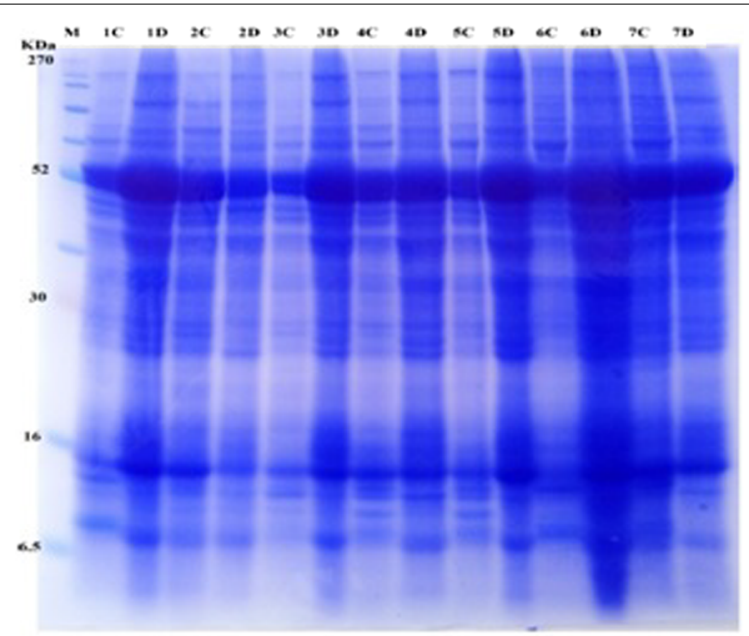

(a)

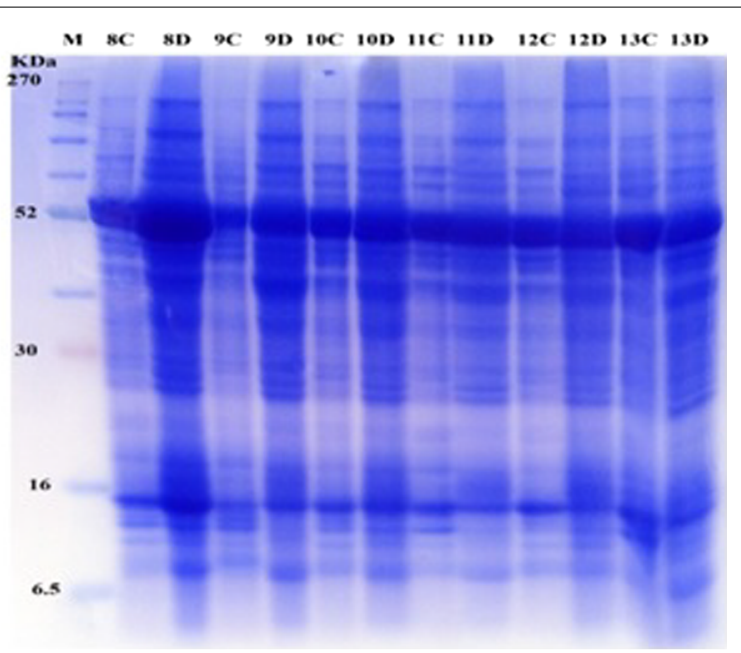

(b)

Fig. 3 Total proteins banding pattern using SDS-PAGE technique of studied Egyptian wheat genotypes under the effect of drought stress. a 1-7: Sakha 94, Sakha 93, Gemmieza 10, Misr 2, Sids 1, Sids 12, Giza 168. b 8-13: Misr 1, Shandaweel1, Line 12, Line 18, Line 20, Gemmieza 9. M: protein marker. C: well-watered plant. D: plants under drought stress

Genotypes Misr 2, Sids 1 and Shandaweel1 showed the highest bands disappearance by six and five bands, respectively, under stress relative to their controls.

Twelve new bands may reflect new gene expression under drought stress and form certain proteins with differences in molecular weight. These proteins may be related to drought stress tolerance, such as proteins at molecular mass $135 \mathrm{KDa}$ in genotypes (Gemmieza 10, Shandaweel1, line 18 and line 20), $108 \mathrm{KDa}$ in (Shandaweel 1), $96 \mathrm{KDa}$ (line 18), $90 \mathrm{KDa}$ in genotypes (Gemmieza 10 and Giza 168), 75 KDa in (Sakha 93, Masr1, lines 12 and 20), $36 \mathrm{KDa}$ in (Gemmieza 9 and lines 18 and 20), $32 \mathrm{KDa}$ in genotypes (Sids 12, Giza 168, Masr 1 and Gemsa 9), 26 KDa in genotypes (Sakha 93, Masr2, Masr1, Shandaweel 1, lines 12, 8, 20 and Gemmieza 9), $23 \mathrm{KDa}$ in genotypes (Sids 1, Sids 12 and line18), $16 \mathrm{KDa}$ in genotypes (Gemmieza 10, lines 18 and 20), $11 \mathrm{KDa}$ in (line 18) and $5 \mathrm{KDa}$ in genotypes (Sakha 94 and Gemmieza 10).

There are some genes turned off under drought stress and its proteins disappeared under this environmental effect, such as proteins at molecular mass $185 \mathrm{KDa}$ in genotypes (Misr 2, Giza168, Lines 12, 18 and 20), 150 KDa in genotypes (Sakha 94, Sakha 93, Misr 1, Shandaweel1, Gemmieza 9), $135 \mathrm{KDa}$ in genotypes (Misr 1, Gemesa9), $108 \mathrm{KDa}$ in genotypes (Gemesa10, Misr 2, Sids1, Sids 12, Giza 168, Masr1), 103 KDa in genotypes (Line 18, Gemmieza 9), $96 \mathrm{KDa}$ in genotypes (Sakha 94, Sakha 93, Gemmieza 10, Sids1, Misr 1), 85 KDa in (Sakha 94, Sakha 93, Misr 2, Sids1, Giza 168, Masr1, Shandaweel1, Lines 12, 18 and 20), $60 \mathrm{KDa}$ in genotypes (Sakha 93, Gemmieza 10, Masr1, Shandaweel1,
Gemmieza 9), 27 KDa in (Sakha 93, Misr 2, Masr1, Shandaweel1, Lines 12,18\&20,Gemmieza 9), 23 KDa in (Sakha 93, Giza 168, Shandaweel1), 13 KDa in (Gemesa10, Misr 2, Sids1, Sids 12, Giza 168, Masr1, Shandaweel1, Line 12), $12 \mathrm{KDa}$ in (Shandaweel1) and $5 \mathrm{KDa}$ in (Masr1, Shandaweel1, Lines 12, 18 and 20).

\section{Proline estimation under the effect of water regime}

The obtained data revealed that proline concentration was significantly increased under water regime in most experimented genotypes relative to the unstressed genotypes except Misr 1 (14.55 $\mu$ mole/g) and line 18 $(13.19 \mu \mathrm{mole} / \mathrm{g})$ genotypes.

As shown in Table 6, the free proline was maximum in Misr 2 (34.76 $\mu$ mole/g) followed by line 12, Sids 12, Shandaweel1 and Gemmieza 9 genotypes, respectively, in a way that emphasized their tolerance to water shortage. The minimum free proline content was recorded after Sids $1(11.01 \mu \mathrm{mole} / \mathrm{g})$, Misr 1 and Line 18 genotypes by the way they declare their sensitivity to the water shortage.

\section{The effect of water regime on betaine aldehyde dehydrogenase-1 gene expression}

Semiquantitative RT-PCR was done to study the expression of the $B A D H-1$ gene under drought conditions. Based on our field measurements for yield criteria and the Egyptian atlas for wheat agriculture, we selected six genotypes among the studied genotypes. Three of them were tolerant in addition the other three of sensitive to water deficit (Sakha 94, Misr 2, Line 18, Sakha 93, Giza 


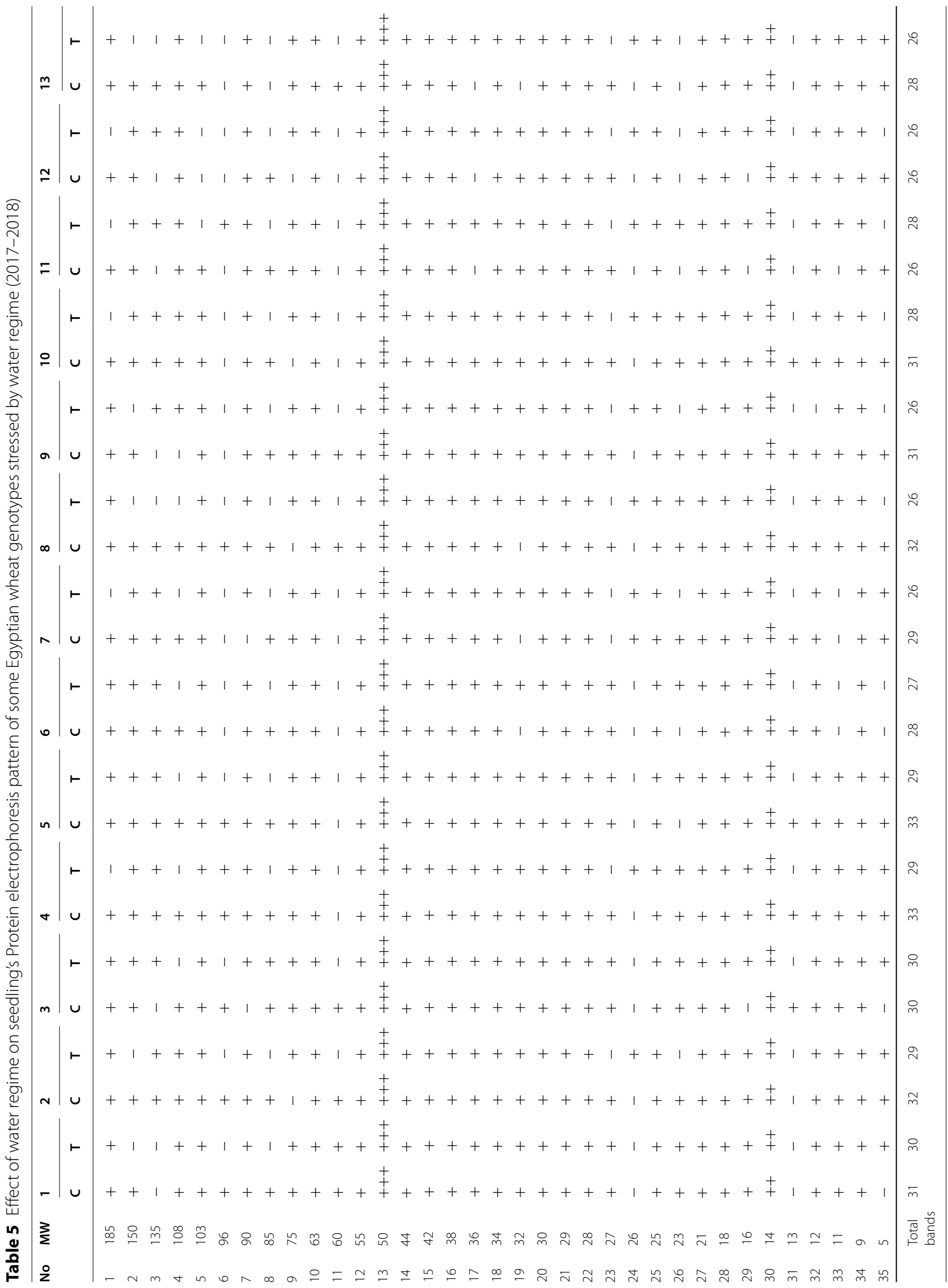


Table 6 The free proline concentration ( $\mu$ mole/g) in the leaves of thirteen varieties of Egyptian wheat under water regime (2017-2018)

\begin{tabular}{lcc}
\hline Wheat genotype & $\begin{array}{l}\text { Control } \\
\text { Mean } \pm \text { SD }\end{array}$ & $\begin{array}{l}\text { Draught } \\
\text { Mean } \pm \text { SD }\end{array}$ \\
\hline Sakha 94 & $12.16 \pm 0.12$ & $12.52 \pm 0.73$ \\
Sakha 93 & $10.80 \pm 0.09$ & $11.59 \pm 0.03$ \\
Gemmieza 10 & $10.92 \pm 0.64$ & $17.58 \pm 0.39$ \\
Misr 2 & $11.19 \pm 0.24$ & $34.76 \pm 0.39$ \\
Sids 1 & $11.46 \pm 0.27$ & $11.01 \pm 0.61$ \\
Sids 12 & $10.59 \pm 0.54$ & $17.91 \pm 0.42$ \\
Giza 168 & $9.89 \pm 0.33$ & $12.16 \pm 0.24$ \\
Misr 1 & $15.43 \pm 0.42$ & $14.55 \pm 0.03$ \\
Shandaweel1 & $13.37 \pm 0.48$ & $17.88 \pm 0.09$ \\
Line 12 & $15.37 \pm 0.24$ & $24.96 \pm 0.45$ \\
Line 18 & $13.49 \pm 0.12$ & $13.19 \pm 0.48$ \\
Line 20 & $10.44 \pm 0.70$ & $12.28 \pm 0.30$ \\
Gemmieza 9 & $10.74 \pm 0.09$ & $15.19 \pm 0.48$ \\
\hline
\end{tabular}

168 and Gemmieza 9). The amplified band was visualized at molecular size $410 \mathrm{bp}$ (Fig. 4). The band intensity of the $B A D H-1$ gene under drought stress was higher than in control as shown with Sakha 94, line 18 and Sakha 93 genotypes. In contrast, Misr 2, Giza 168 and Gemmieza 9, the intensity of $B A D H-1$ gene under drought stress was less than in the control. It is also clear that Line 18 showed the maximum expression in the $B A D H-1$ gene, while Gemmieza 9 showed the least gene expression under drought stress (Fig. 5).

\section{Discussion}

Water shortage and drought can reduce the plants yield dramatically. For example, reducing the irrigating water by $40 \%$ can reduce the wheat plant yield by $21 \%$ (Daryanto et al. 2016). From our results, we observed the reduction in means yield traits value by the waterstarve compared to the control. These results were agreed with Mariey (2004) and Oraby et al. (2005), who found that, the salt stress (which mostly resembles the effect of drought abiotic stress in its consequences on plant interaction) reduced number of tillers, plant height, days to heading, number of spike/plant and grain yield, our results also agree with Mostafa et al. (2016) results in a number of spike/plant and grain yield of barley.

On collecting the obtained yield data together, the tested wheat genotypes responded to the stress in a fluctuated way; most of the tested criteria under water regime showed reduction if compared with well-watered genotypes, but all in all, they could stand to produce grains in a full life cycle after the two seasons of stress.
It is well known that abiotic stress such as drought casts its shadow on the plant life, which depends mainly on water to uptake nutrients and carry on all the physiological missions. Also, water-shortage during plant life alerts the plant to enclosure its stomata in order to reduce the water loss via transpiration; this itself rises the plant temperature and enlarges the stress consequences (Haworth et al. 2018).

The obtained data revealed a notable reduction in the spike length after stress, same was previously obtained by Punia et al. (2011) when tested the heat stress on bread wheat and assign it to the physiological response mechanism to the stress, that enforces the plant to early entrance to the reproductive stage to keep its species over the expense of growth period by reducing the division and cell elongation process, While the improvement in the spike length of some genotypes in the second season may reflect the plant genotype adaptation and stress tolerance mechanism. This mechanism may be controlled by stress-related candidate gene(s) or gene block(s) or may be due to the accumulation of several osmo-protectants, compatible solutes, ROS and antioxidants were as a response to dehydration (Budak et al. 2013).

Anthesis and pollination stages are extremely susceptible to water shortage, and its failure directly affects grain number, thus causing a substantial reduction in grain yield (Cattivelli et al. 2008). Sids 12, Shandaweel1, Gemmieza 9 and Misr 2 showed the highest grain number/ plant showed good performance in the pollen viability validation test. The lowering in grain number scored with line 18 may be explained by stress response which leads to produce a higher percentage of pollen sterility which in turn reduce the grain numbers.

The reduction in pollen viability of sensitive genotypes may be resulted from the effect of the drought stress on the plants hormones and metabolites during the floral organs formation stage. In the same trend (Smith and Zhao 2016; Marine et al. 2014; Yan et al. 2012) stated that the abiotic stress produced defected hormones which produced abnormal male and female floral organs development that exhibits the nutrients translocation, leads to male and female sterility.

The loss in pollen viability after abiotic stress may refer to the poor nutrition through anthesis stage. In agreement with Vara Prasad and Djanaguiraman (2014); who referred the reduction in pollen viability of wheat after temperature elevation to the induced deformation in tapetal cells which are responsible for nutrient translocation to the developing pollen leads to pollen viability loss and or deformation. Also, the pollen viability reduction may be controlled by the sugary contents and the ability to mobilize the carbon sources (Muhammad et al. 2019). In the same track Dorion et al. (1996) and Lalonde et al. 
(1997) who stated that water shortage at the anthesis stage of wheat induced reductions in invertase activity and starch accumulation which are responsible for pollen sterility as pollen cannot metabolize incoming sucrose to hexoses if invertase activity is limiting.

It is well known that plant stomata enclosure a defense mechanism to drought stress reduces photosynthesis simultaneously; it forces plants to use stored starch as an energy source. The adverse effect of stress is reduced in the plant by releasing some compatible solutes, osmoprotectants, derived sugars and other metabolites to encourage plant growth (Yadav et al. 2020). Based on that fact, the unexpected maintenance in the pollen viability of the tolerant genotypes after such stress may be explained by the interference of some genetic factors that may improve the stressed plant's behavior to keep its life under such stress. For example, starch biosynthesis during the pollen maturation process is considered as a quality controller for pollen because starch provides pollens with the energy necessary for germination. It also serves as a checkpoint of pollen maturity.

Pollen sterility decreases pollen germination, hinders pollen tube growth to impair fertilization and reduces seed yield (Fang et al. 2010; Gusmao et al. 2012). Thus, it in turn refers to the damaging effect of drought stress at the reproductive stage. It is well known that starch and other carbohydrates are the main constituents of wheat grains $(71.18 \%)$ give it the highest value among other cereals (Rehman et al. 2009); based on this the reduction in grains' weight or size may be a negative sign on grain quality. The observed reduction weight grains weight may reflect a plants' physio-response to the stress by shortening the grain-filling period, which is an enzymatically dependent process of starch biosynthesis and accumulation. Enzymes such as sucrose synthase, soluble starch synthase and the starch branching enzyme in their activity levels are involved in the grain filling process (Yang et al. 2004), when stress affects these enzymes activity; grains fail to accumulate carbohydrates in the right content and fails to reach the right size which in turn affect the quality. Liu et al. (2004) previously stated that drought had a notable effect on carbohydrate metabolism in plants, ultimately affecting both biological and economical yields. Bala et al. (2014) also recorded a significant reduction in grains' weight as a response to heat stress on wheat plants during the filling period. Also, in agreement with (Saini and Westgate 2000), who stated the drought effect during the early stage of grains development reduces the number of endosperm cells. In this condition, the wheat grain become shriveled and less in size and resultantly test weight reduces.

The induced change in the proteins banding pattern resulting from stress refers to a mutational event at the regulatory system of an unexpected gene(s) as a defense response in the plants (Adam et al. 2017).

The above results declare that the protein profile changed between the stressed plant and non-stressed plant and among different genotypes, no new band or missing band could discriminate the stress response. For example, the band at molecular weight $26 \mathrm{KDa}$ appeared in the tolerant wheat genotypes (Misr 2, Sids 12, Shandaweel1, Gemmieza 9 and Line 12) and appeared as a new band in some sensitive genotypes as Line 18. Also, the disappearance of band at molecular weight $85 \mathrm{KDa}$, which disappeared from sensitive wheat genotypes (Sids 1, Masr1, Giza 168 and line 18), was also absent in some tolerant wheat genotypes (Misr 2, Shandaweel1).

The undiscriminating effects of the protein banding patterns among wheat genotype agreed with (Tanksley and Jones 1981; Reza and Morad 2014), who stated that grain protein banding pattern in more crops is very stable and not sensitive to environmental changes.

This also may be explained by the response to the drought stress as abiotic stress is controlled by multiple genes and is more complicated than the response to the biotic stress which is characterized by a monogenic response (Lamaoui et al. 2018).

Binding the yield performance with reading protein profile gave undirected results; it may be due to the age of the plant at the time of the experiment. For example, protein banding electrophoresis was carried on plant at the seedling stage, while the yield traits performance was carried out on complete adult plants which may show the difference in the stress response. This may explain the unexpected increase in protein bands in the stress-sensitive genotypes as well as the stress-tolerance genotypes. Mostafa et al. (2016) observed by inspected visually of proteins banding pattern of the ten Egyptian barley genotypes under different salt stress conditions that the maximum polymorphism was documented after 2nd week from salt treatments and show the lowest variation, while after $24 \mathrm{~h}$ and first week from salt treatments showed a maximum variation. This may be due to the adaptation of plants with the salinity and produced the needed proteins which help defending themselves from salt stress.

The free proline concentration in flag leaf was increased in salt-tolerance wheat genotypes over the saltsensitive genotypes (Abu Hasan et al. 2015); our collected data revealed that genotypes Masr1, line 12, Sids 12, Shandaweel1, Gemmieza 9 which show high yield performance under stress were with high proline concentration. Line 18 showed the least adaptation to water regime and scored the least yield performance was with the least proline content.

Also, the proline accumulation level was used successfully by El-Atroush et al. (2020) to study the effect of salt 


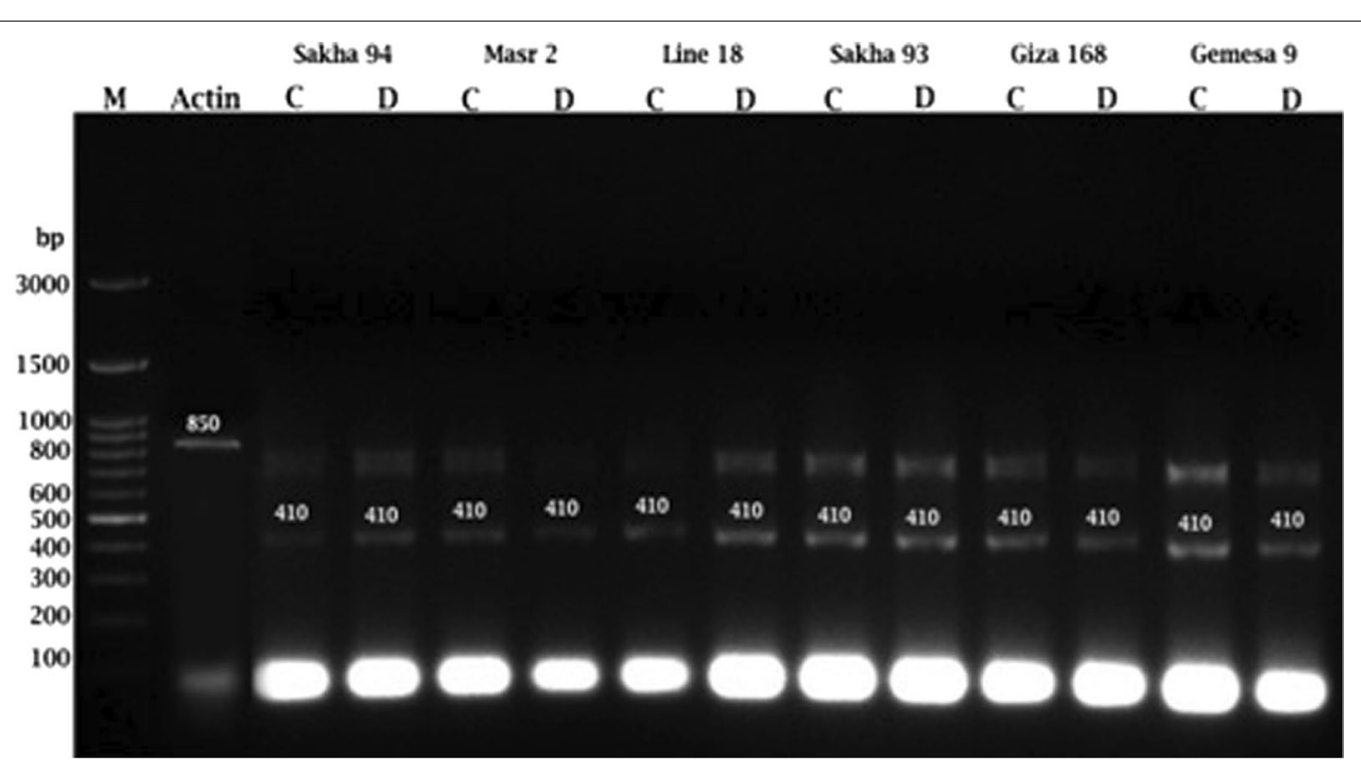

Fig. 4 Electrophoretic profile for PCR product using one specific primer for BADH-1 sequence in CDNA. M=DNA Marker. Actin: internal control. C: well-watered plants. D: plant under stress conditions. Genotypes: $(3,4)$ Sakha 94- $(5,6)$ Misr 2- $(7,8)$ line 18- $(9,10)$ Sakha $93-(11,12)$ Giza 168 and $(13,14)$ Gemmieza 9

\section{pixel intensity (peak hight)}

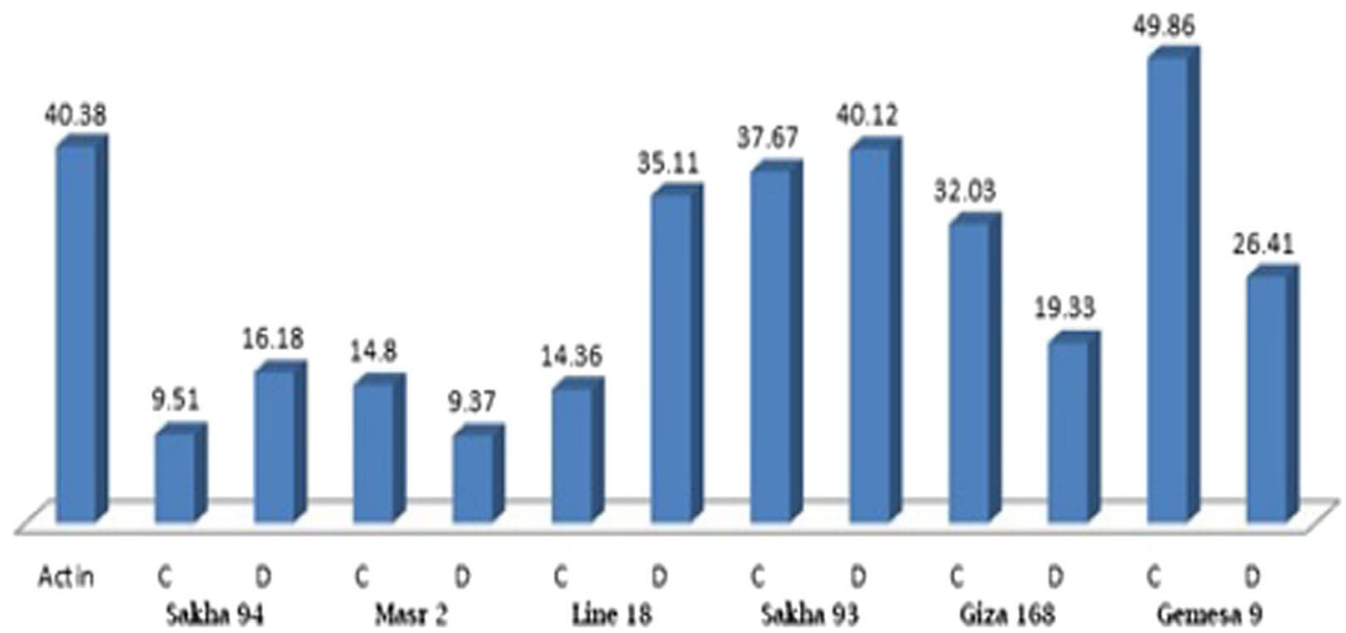

Fig. 5 Pixel intensity of betaine aldehyde dehydrogenase-1 (BADH-1) gene expression in six selected Egyptian wheat genotypes under water regime

stress on ten Egyptian barley genotypes and found that the proline accumulation level is increased by increase in the salinity stress.

On the other point of view, when Nayyar and Walia (2003) examined water stress on two wheat genotypes (tolerant C 306 and susceptible HD 2380), they found that, despite that proline level did not differ between the two genotypes, the rate of proline accumulation was much greater in the tolerant genotype and stated that the proline synthesis rate can be much reliable than proline accumulation. This was argued by Bayoumi et al. (2008), who referred that accumulation in free amino acid mainly depends on excess in proline synthesis over the proline degradation which in turn affect the osmo-protective role against stress. 
Line 18 showed the maximum BADH-1 enzyme accumulation in seedlings' leaves while it showed the least yield parameters in the parent plant at the first season of stress; it announced its sensitivity to water poverty. Also, its protein profile produced higher protein bands number by two new bands relative to well-watered plants.

Simultaneously, Gemmieza 9 which showed the least $B A D H-1$ enzyme production previously declared its tolerance to stress via high yield performance.

This may be explained by the correlation between transcript amount change to the plant stage and in seedling stage the higher transcription amount found in sensitive accession to enhance their effect drought tolerance by accumulating high amount of $B A D H-1$ enzyme. The transcript amounts of the $B A D H-1$ gene under drought stress were more than control in all studied accessions except in Misr 2, Giza 168 and Gemmieza 9. These results agreed with (Harb et al. 2020) when tested the drought stress on two genotypes of barley to identify molecular and biochemical differences between the genotypes. They stated that the degree of upregulation of betaine aldehyde dehydrogenase genes with proven roles in imparting drought tolerance in addition to a homeobox transcription factor were greater in Otis (drought-tolerant) than Baronesse (drought-sensitive).

\section{Conclusion}

The overall view on the gathered data points to the same directed assumption that genotypes Sids 12, Misr 2, Shandaweel1, Gemmieza 9 and Line 12 are the most tolerant genotypes to water shortage as they show the highest performance at all concerned levels. These genotypes are recommended to be planted in regions suffered from water deficit, while the genotypes Giza 168 and Line 18 are considered sensitive to water shortage and recommended to be planted in the Nile delta. These observations may add some new modifications to the current Egyptian wheat atlas in the near future.

\section{Abbreviations}

BA: Betaine aldehyde; BAHD-1: Betaine aldehyde dehydrogenase; DNA: Deoxy ribonucleic acid; GB: Glycine betaine; GN: Number of grains; GYs: Grain yields; RNA: Ribonucleic acid; ROS: Reactive oxygen species; SL: Spike length; SN: Number of spikes; SSI: Stress susceptibility index; SW: Spike weight; TTC: Triphenyl tetrazolium chloride.

\section{Acknowledgements}

The authors wish to express their deep thanks to the National Research Centre, Giza, Egypt, for affording all the requirements and supports to finish this work.

\section{Authors' contributions}

This work was carried out in collaboration between all authors. SAA, SEE designed the study, wrote the protocol, SAA, SEE, AAH participated in field's work, SAO performed protein electrophoresis, proline estimation and determine the betaine aldehyde dehydrogenase gene expression semiquantitatively, RTA carried out the cytological studies, wrote the manuscript, managed the literature searches and managed the paper organization. All authors read and approved the final manuscript.

\section{Funding}

The technical work of this research was funded financially by the Scientific Research Projects Sector-National Research Centre, Egypt. Project no 11030107

\section{Availability of data and materials}

Not applicable.

\section{Declarations}

Ethics approval and consent to participate

Not applicable.

\section{Consent for publication}

Not applicable.

\section{Competing interests}

The authors declare that they have no competing interests.

Received: 29 April 2021 Accepted: 29 August 2021

Published online: 08 September 2021

\section{References}

Abu Hasan H, Rahman H, Nurealam S, Khatun M, Rabiul I, Abdullah A (2015) Evaluation of wheat genotypes for salt tolerance based on some physiological traits. J Crop Sci Biotech 18(5):333-340. https://doi.org/10.1007/ s12892-015-0064-2

Adam ZM, Mikhael E, El- Ashry ZM, Ehsan NO, Ali RT (2017) Potential mutagenic effect of dusting Vicia faba seeds with Malathion 1\% powder or fumigating by Phosphine for storage. Afr J Biol Sci 13(1):23-44

Agricultural ministry flying pursuer, agricultural pesticide committee (2019). http://www.apc.gov.eg/files/academy2017.pdf

Alam SM (1999) Nutrient uptake by plants under stress conditions. In: Pessarakli M (ed) Handbook of plant and crop stress. Marcel Dekker, New York, pp 285-314

Bala S, Asthir B, Bains SN (2014) Effect of terminal heat stress on yield and yield attributes of wheat. Indian J Appl Res 4:1-2

Bates LS, Wladren RP, Teare ID (1973) Rapid determination of free proline for water stress studies. Plant Soil 39(1):205-207

Bayoumi TY, Eid MH, Metwali EM (2008) Application of physiological and biochemical indices as a screening technique for drought tolerance in wheat genotypes. Afr J Biotech 7:2341-2352

Budak H, Kantar M, Kurtoglu KY (2013) Drought tolerance in modern and wild wheat. Sci World J. https://doi.org/10.1155/2013/548246

Cattivelli L, Rizza F, Badeckc FW, Mazzucotelli E, Mastrangelo AM, Franciaa E, Marea C, Tondellia A, Stanca AM (2008) Drought tolerance improvement in crop plants: an integrated view from breeding to genomics. Field Crops Res 105:1-14

Daryanto S, Wang L, Jacinthe PA (2016) Global synthesis of drought effects on maize and wheat production. PLoS ONE 11(5):e0156362. https://doi.org/ 10.1371/journal

Dorion S, Lalonde S, Saini HS (1996) Induction of male sterility in wheat by meiotic-stage water deficit is preceded by a decline in invertase activity and changes in carbohydrate metabolism in anthers. Plant Physiol 111:137-145

El-Atroush H, Essam AHM, Samira AO (2020) Molecular characterization of betaine aldehyde dehydrogenase $(\mathrm{BADH})$ gene and proline estimation in Hordeum vulgare L. in response to abiotic stress. Egypt Acad J Biol Sci 12(2):1-21

Fang X, Turner NC, Yan G, Li F, Siddique KH (2010) Flower numbers, pod production, pollen viability, and pistil function are reduced and flower and 
pod abortion increased in chickpea (Cicer arietinum L.) under terminal drought. J Exp Bot 61 (2):335-345. https://doi.org/10.1093/jxb/erp307

Fischer RA, Maurer R (1978) Drought resistance in spring wheat genotypes. I. Grain yield responses. Aust J Agric Res 29:897-912

Gusmao M, Siddique KHM, Flower K, Nesbitt H, Veneklaas EJ (2012) Water deficit during the reproductive period of grass pea (Lathyrus sativus L.) reduced grain yield but maintained seed size. J Agron Crop Sci 198:430-441. https://doi.org/10.1111/j.1439-037X.2012.00513.X

Harb A, Simpson C, Guo W, Ganesan Govindan G, Kakani VG, Sunkar R (2020) The effect of drought on transcriptome and hormonal profiles in barely genotypes with contrasting drought tolerance. Front Plant Sci 11:618491

Haworth M, Marino G, Brunetti C, Killi D, De Carlo A, Centritto M (2018) The impact of heat stress and water deficit on the photosynthetic and stomatal physiology of olive (Olea europaea L.) - a case study of the 2017 heat wave. Plants 7(76):1-13. https://doi.org/10.3390/plants7040076

Hayat S, Hayat Q, Alyemeni MN, Wani AS, Pichtel J, Ahmad A (2012) Role of proline under changing environments review. Plant Signal Behav 7(11):1456-1466

Hedhly A (2011) Sensitivity of flowering plant gametophytes to temperature fluctuations. Environ Exp Bot 74:9-16. https://doi.org/10.1016/j.envex pbot.2011.03.016

Khatun S, Flowers TJ (1995) The estimation of pollen viability in rice. J Exp Bot 46:151-154

Laemmli UK (1970) Cleavage of structural proteins during the assembly of the head of bacteriophage T4. Nature 227:680-685

Lalonde S, Beebe DU, Saini HS (1997) Early signs of disruption of wheat anther development associated with the induction of male sterility by meioticstage water deficit. Sex Plant Reprod 10:40-48

Lamaoui M, Jemo M, Datla R (2018) Heat and drought stresses in crops and approaches for their mitigation. Front Chem 2018:6. https://doi.org/10. 3389/fchem.2018.00026

Liu F, Jensen CR, Andersen MN (2004) Drought stress effect on carbohydrate concentration in soybean leaves and pods during early reproductive development: its implication in altering pod set. Field Crop Res 86(1):1-13. https://doi.org/10.1016/S0378-4290(03)00165-5

Mariey AS (2004) Genetical and molecular studies on barley salt tolerance. M.Sc. Thesis, Tanta University, Egypt

Marine JP, Adriaan WH, Arnaud GB (2014) The metabolic basis of pollen thermo-tolerance: perspectives for breeding. Metabolites 4:889-920. https://doi.org/10.3390/metabo4040889

Mendieta H, Granados R (2015) Method for improving pollen viability. Int. Nat. Patent Coll. WO2015025034

Mostafa EAH, El-Atroush H, El-Ashry ZM, Mohamed Fl, El-Khodary SE, Osman SA (2016) Genetic variation and agro-morphological criteria of ten Egyptian barley under salt stress. Int J ChemTech Res 9(7):119-130

Muhammad KR, Saeed R, Mohsin K, Shahid I, Javaid AB, Ayaz F, Adeel R, Guangnan X, Junyi G (2019) Pollen Viability an index of abiotic stresses tolerance and methods for the improved pollen viability. Pak J Agric Res 32(4):609-624

Nayyar H, Walia DP (2003) Water stress induced proline accumulation in contrasting wheat genotypes as affected by calcium and abscisic acid. Biol Plant 46(2):275-279

Norton JD (1966) Testing of plum pollen viability with tetrazolium salts. J Am Soc Hortic Sci 89:132-134

Oraby HF, Ransom CB, Kravchenko AN, Sticklen MB (2005) BarleyHVA1gene confers salt tolerance in R3transgenic oat. Crop Sci 45:2218-2227

Punia S, Shah A, Ranwha B (2011) Genetic analysis for high temperature tolerance in bread wheat. Afr Crop Sci J 19:149-163
Rehman A, Habib I, Ahmad N, Hussain M, Khan A, Farooq J, Ali M (2009) Screening wheat germplasm for heat tolerance at terminal growth stage. Plant Omics J Southern 2:9-19

Reza AP, Morad S (2014) Study on protein changes in wheat under drought stress. Int J Adv Biol Biomed Res 2(2):317-320

Saini HS, Westgate ME (2000) Reproductive development in grain crops during drought. In: Spartes DL (ed) Advances in agronomy, vol 68. Academic Press, SanDiego, pp 59-96

Sakhi S, Okuno K, Shahzad A, Jamil M (2014) Evaluation of sorghum (Sorghum bicolour L.) core collection for drought tolerance: pollen fertility and mean performance of yield traits and its components at reproductive stage. Int J Agric Biol 16:251-260

Shpiler L, Blum A (1991) Heat tolerance for yield and its components in different wheat cultivars. Euphytica 51:257-263

Shrestha K (2011) Analysis of betaine aldehyde dehydrogenase encoding genes in wheat. M.Sc. thesis, Southern Cross University, Lismore, NSW

Smith AR, Zhao D (2016) Sterility caused by floral organ degeneration and abiotic stresses in Arabidopsis and cereal grains. Front Plant Sci 7:1-15. https://doi.org/10.3389/fpls.2016.01503

Studier FW (1973) Analysis of bacteriophage T1 early RNAs and proteins of slabgels. J Mol Biol 79:237-248

Tanksley SD, Jones RA (1981) Application of alcohol dehydrogenase allozymes in testing the genetic purity of F1 hybrids of tomato. Hort Sci 16:179-181

Vara Prasad PV, Djanaguiraman M (2014) Response of floret fertility and individual grain weight of wheat to high temperature stress: sensitive stages and thresholds for temperature and duration. Funct Plant Biol 41:1261-1269. https://doi.org/10.1071/FP14061

Yadav S, Payal M, Akanksha D, Akdasbanu V, Disha P, Mohini P (2020) Effect of abiotic stress on crops. Sustain Crop Prod 4:1-21. https://doi.org/10.5772/ intechopen.88434

Yan Y, Christensen S, Isakeit T (2012) Disruption of OPR7 and OPR8 reveals the versatile functions of jasmonic acid in maize development and defence. Plant Cell 24:1420-1436. https://doi.org/10.1105/tpc.111.094151

Yang J, Zhang J, Wang Z, Xu G, Zhu Q (2004) Activities of key enzymes in sucrose-to-starch conversion in wheat grains subjected to water deficit during grain filling. Plant Physiol 135:1621-1629

Yu HQ, Zhou XY, Wang YG (2017) A betaine aldehyde dehydrogenase gene from Ammopiptanthus nanus enhances tolerance of Arabidopsis to high salt and drought stresses. Plant Growth Regul 83:265-276

Zadoks JC, Chang TT, Konzak CF (1974) A decimal code for the growth stages of cereals. Weed Res 14:415-421. https://doi.org/10.1111/j.1365-3180. 1974.tb01084

Zandalinas SI, Sales C, Beltrán J, Gómez-Cadenas A, Arbona V (2017) Activation of secondary metabolism in citrus plants is associated to sensitivity to combined drought and high temperatures. Front Plant Sci 7:1-17. https://doi.org/10.3389/fpls.2016.01954

Zhu JK (2001) Plant salt tolerance. Trends Plant Sci 6:66-71

Zlatev Z, Lidon FC (2012) An overview on drought induced changes in plant growth, water relations and photosynthesis. Emir J Food Agric 24:57-72. https://doi.org/10.9755/ejfa.v24i1.10599

\section{Publisher's Note}

Springer Nature remains neutral with regard to jurisdictional claims in published maps and institutional affiliations.

\section{Submit your manuscript to a SpringerOpen ${ }^{\circ}$ journal and benefit from:}

- Convenient online submission

- Rigorous peer review

- Open access: articles freely available online

- High visibility within the field

- Retaining the copyright to your article

Submit your next manuscript at $\boldsymbol{\nabla}$ springeropen.com 